\title{
Analysis of Genesis Rain in Spring Transition in Makassar
}

\author{
Candra Febryanto Patandean \\ Meteorology, Climatology and Geophysics Agency IV Makassar \\ Email: candrafebryanto@yahoo.com
}

\begin{abstract}
Extreme weather in this case heavy rains is common in the city of Makassar, both of which resulted in a flood or no flood. This type of research is descriptive research that aims to describe the incidence of rain in the transition season in Makassar. The source of data used in obtaining data on research in Makassar is secondary data. His research methods such as analysis method is based on monthly rainfall data to determine the monthly rainfall pattern using the Log Pearson III distribution methods and daily rainfall data duration of 3 hours early to analyze the frequency of rain by using Gumbel distribution methods. Based on the results in a graph of monthly rainfall patterns in the city of Makassar in the year (19852014) for 30 years and chart the frequency of daily rainfall duration 3 hours late in the year (2005 to 2014) for 10 years in the transition season in the city of Makassar, we can conclude that monthly rainfall patterns in Makassar is a monsoonal pattern with the second-largest peak intensity of rainfall occurs in January and December and the smallest intensity of rainfall occurs in August.
\end{abstract}

Keywords: Rainfall; Rain Patterns; Frequency Rain; Transition Season.

\section{INTRODUCTION}

Makassar City is the fourth largest city in Indonesia and the largest in Eastern Indonesia (KTI) has an area of $175.77 \mathrm{~km}^{2}$ with a population of $1,429,242$, so the city has become a Metropolitan city. The city is at an altitude between $0-25 \mathrm{~m}$ from sea level. The population of Makassar City in 2014 was 1,429,242 people consisting of 706,814 people and 722,428.

Extreme rain is one of the meteorological phenomena that has the most severe damaging effects because it can usually cause flash floods and is sometimes followed by bad weather such as lightning, hail, very strong surface winds and vertical wind shears (Jones, 2004). In rural areas, extreme rain can damage crops and livestock, while in urban areas, inadequate drainage systems to accommodate the amount of rainwater that suddenly increase dramatically (Carvalho, 2002). The women with an average population growth of $1.50 \%$. The city of Makassar with a population of 1,429,242 people, the majority of the population is Muslim and the rest are Christian, Catholic, Hindu and Buddhist. there is a line of windfall (convergence) that triggers convection activity and strong vertical air movement (Davolio, 2012).

Rainfall varies greatly according to place and time (Handoko, 1994), its volume and intensity can change rapidly (Galvan, 2013). Its distribution and diversity is influenced by various factors such as geographic location, topography, and upper air flow (Hilario, 2009). Furthermore, variations in rainfall of a region, especially Indonesia as a maritime continent (Hendon, 2003; Qian, 2008) are closely related to the interaction and fluctuations of phenomena 
178 Jurnal Administrare: Jurnal Pemikiran Ilmiah dan Pendidikan Administrasi Perkantoran
Volume 6 Number 2 July- December 2019. Pages 177-188

caused by atmospheric-oceanic dynamics (Giannini, Robertson, \& Qian, 2007; Ropelewski \& Halpert, 1987)

According to (Nontji, 2002) study of the transition season, information is obtained that the factor of sea surface temperature is also influenced by meteorological conditions such as evaporation, rainfall, air temperature, air humidity and wind speed because surface temperature usually follows a seasonal pattern. As a result, during the pan-caroba season (transition season), the surface layer temperature reaches its maximum. Based on the description of rainfall events, the transition season, and the analysis of the rainfall, the authors are interested in examining the Analysis of the Occurrence in the Transition Season in the City of Makassar.

The formulation of the problem studied in this study is a. What is the pattern of monthly rainfall that occurred in Makassar City in 1985-2014 for 30 years? b. What is the frequency of rain in the morning, afternoon and night that occurs in Makassar City in the period 2005-2014 (10 years) in the transition season?. The research objectives are a. Determine the monthly rainfall pattern that occurred in Makassar City in 1985-2014 for 30 years. b. Analyzing the frequency of rain in the morning, afternoon, and night which occurred in Makassar City in 2005-2014 for 10 years in the transition season.

\section{METHOD}

This type of research is descriptive research. This descriptive study is a study that seeks to describe the incidence of rain in the transitional seasons of Makassar City.

The research instrument used consisted of tools and materials in the process of retrieving data as follows: Observatory type rain gauge (Obs) using a standard measuring cup with a scale of $0-25 \mathrm{~mm}$, hellman type semi automatic rain gauge, hardware in the form of a computer or laptop, software in the form of Mic-rosoft Office software, Canon Pixma 277 printer, camera, and flash disk.

Data sources used in data collection in research in Makassar City are as follows: secondary data of 3 hours daily rainfall duration, secondary data of 3 hours daily rainfall is the data obtained from the BBMKG Wil.4 Makassar web in the form of daily duration of 3 hours of rainfall in the years (2005-2014) for 10 years, namely the location at the Meteorological station Hasanuddin (location that represents the primary city). Methods Analysis of data based on monthly rainfall data is used to determine the monthly rainfall pattern for the year (1985-2014) for 30 years using the Log Pearson III distribution method and the three hour duration rainfall data used to analyze the frequency of rain in the year (2005-2014) for 10 years using the Gumbel distribution method. The following is the Log Pearson III distribution method and the Gumbel distribution method as follows:

$$
\bar{X}=\frac{\sum_{i=1}^{n} \log X_{i}}{n}
$$

(sumber: Soewamo, 1995)

Where: $x=$ average monthly rainfall value

$\mathrm{xi}=$ rain value on $\mathrm{i}$

$\mathrm{n}=$ the amount of rainfall data (Soewarno, 1995) 
Gumbel Distribution Method In using the disformula method Gumbel distribution is to find the frequency of rain based on daily average duration data 3 hours of the period (2005-2014) during 10 years as follows:

$$
\begin{gathered}
\mathrm{X}_{\mathrm{T}}=\mathrm{X}+\mathrm{S} \cdot \mathrm{K} \\
\quad \text { or } \\
\mathrm{K}=\frac{\mathrm{X}_{\mathrm{T}-}}{\mathrm{S}}
\end{gathered}
$$

Where:

$\mathrm{XT}$ : Estimated rainfall value that is expected to occur with a period of time

$\mathrm{X}$ : Average price of rainfall data

$\mathrm{S}:$ Standard deviation of rainfall data

$\mathrm{K}$ : frequency of rain (Soewarno, 1995)

\section{RESULT AND DISCUSSION}

From the results of data processing of rainfall patterns in the period 1985-2014, the results of the study are as follows:

\section{Monthly Rainfall Pattern Analysis in Makassar City in the years (1985-2014) for 30 years}

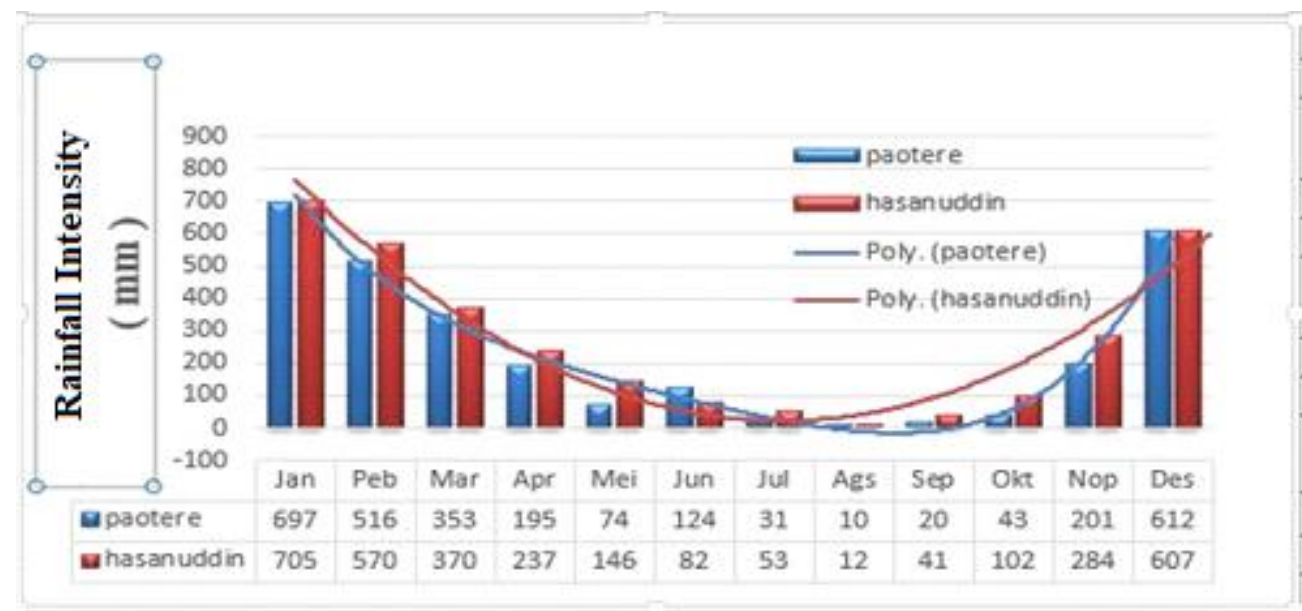

Figure 1 Monthly Rain Pattern Monsunal in Makassar City for 30 years (1985 - 2014).

Based on the figure 1 above, the graph of monthly rainfall patterns in Makassar city is the result of processed monthly average rainfall data (Hasanuddin station monthly rainfall data and Paotere station rainfall data) in 1985-2014 for 30 years is a type of monsoonal rain pattern. The monsoonal rainfall pattern is the " $\mathrm{V}$ " shaped monthly rainfall distribution pattern with the lowest monthly rainfall intensity occurring in August. In figure graph 4.1 the monsoonal 
180 Jurnal Administrare: Jurnal Pemikiran Ilmiah dan Pendidikan Administrasi Perkantoran

Volume 6 Number 2 July- December 2019. Pages 177-188

monthly rainfall pattern of Makassar City can be explained every month from January to December as follows:

In January, based on a graph of monthly rainfall patterns monsoonal, the city of Makassar in January has a monthly monsoonal rainfall pattern with monthly rainfall values above 600 $\mathrm{mm}$. The high rainfall in Makassar City this month is due to the situation of the city which is located on the coast of the South Sulawesi peninsula, which in the middle is a hill row. In the area of Makassar City this month brought wet air which gave the orographic effect of rain shadow (Fohn efect).

In February, based on the graph, the monsoonal monthly rainfall pattern in February has a monthly rainfall intensity of more than $500 \mathrm{~mm}$, where the difference in rainfall intensity is not much different in January. With a decrease in the intensity of rainfall of more than $100 \mathrm{~mm}$ from January to February that occurs in all areas of the City of Makassar, while the orographic effect of the shadow of the rain brings wet air masses into the mountains or highlands.

In March, based on the graph of the monsoonal monthly rainfall pattern in Makassar City, in March it still shows a monthly rainfall pattern similar to the monthly rainfall pattern in January and February with the intensity of rainfall in March reaching more than $350 \mathrm{~mm}$ and monthly rainfall patterns on the month March experienced a decrease in intensity similar to the monthly rainfall pattern in February.

In April, Makassar City began to enter the Australian monsoon which has dry physical properties. Based on the graph of the monsoonal monthly rainfall pattern in Makassar City has a monthly rainfall intensity of more than $150 \mathrm{~mm}$ in March. This month the monthly rainfall pattern occurs due to local disturbances so that the supply of wet air gradually decreases.

In May, based on the graph of the monsoonal monthly rainfall pattern in Makassar City this month shows the intensity of rainfall is quite evenly ranging between $(70 \mathrm{~mm}$ to $150 \mathrm{~mm}$ ) in almost all of Makassar City. It can be said that this month has entered the transition season.

In June, based on the graph, the monsoonal monthly rainfall pattern in Makassar city this month was marked by the increasingly widespread transition season in South Sulawesi. All of South Sulawesi have entered the transition season with a number of Makassar cities in the vicinity followed by a transition season. Based on the graph of the monthly rainfall pattern in the city of Makassar the rainfall intensity is less than $150 \mathrm{~mm}$, where the city of Makassar during the transition season has rainfall intensity ranging from $70 \mathrm{~mm}$ to $120 \mathrm{~mm}$.

In July, based on the graph of the monsoonal monthly rainfall pattern in the city of Makassar in July, it showed a decrease in rainfall intensity in the transition season towards the middle season, in this case Makassar City has less than $100 \mathrm{~mm}$ rainfall intensity, ie $30 \mathrm{~mm}$ to $50 \mathrm{~mm}$. The area in the transition season to the dry season starts from Makassar City to expand to the northern part of South Sulawesi.

In August, the entire region of South Sulawesi, especially the city of Makassar, entered the dry season. It can be said that the peak of the dry season occurred this month. The dry season occurs in the entire region of South Sulawesi, especially in the city of Makassar. Based on the monthly monsoonal rainfall pattern in the city of Makassar this month has the intensity of rainfall reaching less than $50 \mathrm{~mm}$, namely rainfall between $10 \mathrm{~mm}$ to $15 \mathrm{~mm}$.

September is the beginning of the Australian monsoon decay which is described by the addition of a little rain in the dry season. Areas with minimal rainfall occurred in South Sulawesi, especially in Makassar City which began to appear increase in rain intensity. Based 
on the graph, the monthly rainfall pattern in Makassar City this month has a rainfall intensity of less than $50 \mathrm{~mm}$, namely rainfall between $20 \mathrm{~mm}$ and $40 \mathrm{~mm}$ this month.

In October, fom the monsoonal monthly rainfall pattern in October there was a movement from the dry season which turned to the rainy season in Makassar City. Another interesting thing is the coming of the Asian monsoon influence which is seen with the emergence of potential rain in the northern part of South Sulawesi which is close to the Asian Continent. Therefore, based on the monthly monsoonal rainfall pattern in Makassar City, the intensity of rainfall is more than $50 \mathrm{~mm}$, which is rainfall between $40 \mathrm{~mm}$ and $100 \mathrm{~mm}$ this month.

In November, the monsoonal monthly rainfall pattern on this island shows the influence of Australian sun and the entry of Asian monsoon with wet air so that in the northern region of South Sulawesi there appears to be a significant increase in the month's rainfall. Based on the graph of the monthly rainfall pattern in the area of Makassar City receives rainfall with an intensity of rainfall greater than $100 \mathrm{~mm}$ which is $200 \mathrm{~mm}$ of rainfall this month. So it can be said that this month the winter has disappeared and has been replaced by the presence of the wet Asian monsoon.

In December, this last month can be seen that the Asian monsoon pattern is dominant in the western part of South Sulawesi. Increased rainfall intensity occurs in almost all areas of South Sulawesi, especially in Makassar City. Areas that have high rainfall based on monthly monsoonal rainfall patterns such as those in Makassar City have an increasing rainfall intensity this month with rainfall greater than $600 \mathrm{~mm}$.

Frequency of Rain in the Morning, Daytime and Nighttime that occurred in Makassar City in 2005-2014 for 10 years in the Transition Season (Transition Season I and Transition Season II)

Transition Season I (Occurs in April and May).

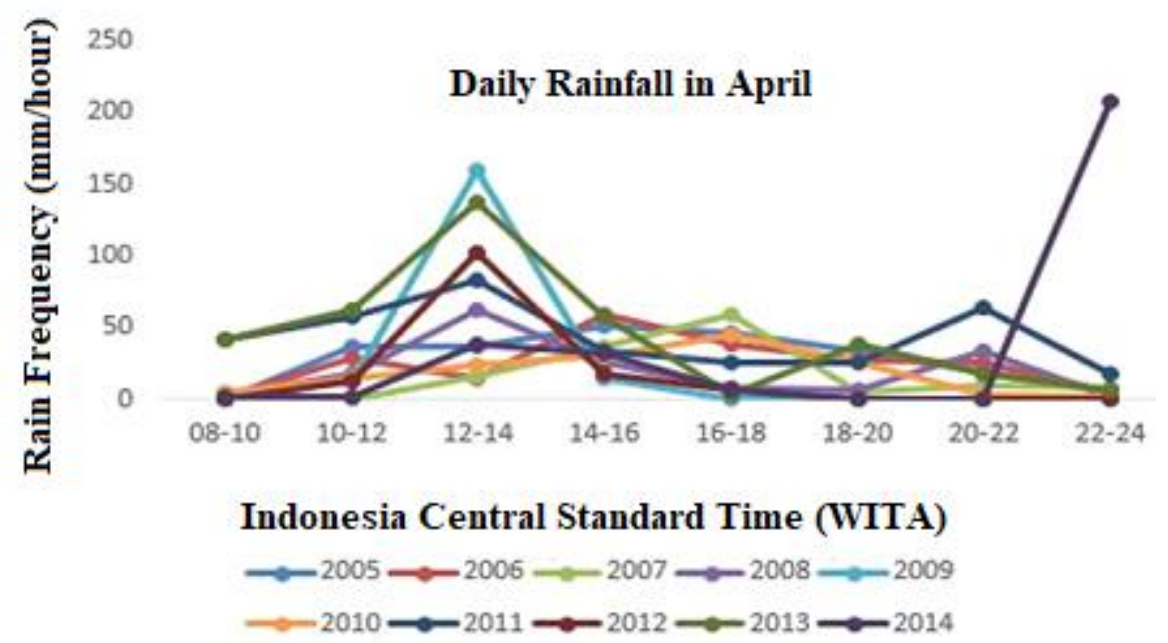

Figure 2. Bulk frequency for a daily duration of 3 hours in April in Makassar.

Based on figure 2 is a graph of the frequency of daily duration of 3 hours duration in Makassar which has been processed in 2005-2014 for 10 years in April as follows:

In April 2005 showed that the frequency of rain occurred in the morning (08.00-12.00 
182 Jurnal Administrare: Jurnal Pemikiran Ilmiah dan Pendidikan Administrasi Perkantoran

Volume 6 Number 2 July- December 2019. Pages 177-188

hours) at $37 \mathrm{~mm} / \mathrm{hour}$, then the frequency of rain occurred during the day (12.00-18.00 hours) as much as $51 \mathrm{~mm} /$ hour, and frequency rain occurs at night (18.00-24.00 hours) as much as 34 $\mathrm{mm} /$ hour.

In April 2006, the frequency of rain occurred in the morning (08.00-12.00 hours) as much as $29 \mathrm{~mm} /$ hour, then the frequency of rain occurred during the day (12.00-18.00 hours) at 60 $\mathrm{mm} /$ hour, and frequency of rain occurs at night (18.00-24.00 hours) a total of $27 \mathrm{~mm} /$ hour.

In April 2007 showed that the frequency of rain occurred in the morning (08.00-12.00 hours) as much as $5 \mathrm{~mm} /$ hour. then the frequency of rain occurs during the day (12.00 - 18.00 hours) as much as $59 \mathrm{~mm} /$ hour, and the frequency of rain occurs at night (18.00 - 24.00 hours) as much as $10 \mathrm{~mm} /$ hour.

In April 2008 showed that the frequency of rain occurred in the morning (08.00-12.00 hours) at $17 \mathrm{~mm} /$ hour, then the frequency of rain occurred during the day (12.00-18.00 hours) as much as $62 \mathrm{~mm} /$ hour, and the frequency of rain occurs at night (18.00-24.00 - wita) as much as $34 \mathrm{~mm} /$ hour.

In April 2009 showed that the frequency of rain occurred in the morning (8:00 a.m. to 12:00 a.m.) a total of $13 \mathrm{~mm} /$ hour, then the frequency of rain occurred during the day (12:00 to 18:00 hours) as much as $160 \mathrm{~mm} /$ hour, while the frequency of rain at night (20.00-24.00-wita) does not occur because there is no rain.

In April 2010 it was shown that the frequency of rain occurred in the morning (8:00 a.m. to 12:00 a.m.) a total of $15 \mathrm{~mm} / \mathrm{hour}$, then the frequency of rain occurred during the day (12:00 to 18:00 hours) as much as $45 \mathrm{~mm} /$ hour, and the frequency of rain occurs at night (18.00-24.00wita) as much as $25 \mathrm{~mm} /$ hour.

In April 2011 showed that the frequency of rain occurred in the morning (08.00-12.00 hours) at $57 \mathrm{~mm} /$ hour, then the frequency of rain occurred during the day (12.00-18.00 hours) as much as $84 \mathrm{~mm} /$ hour, and the frequency of rain occurs at night (18.00-24.00-wita) as much as $64 \mathrm{~mm} /$ hour.

In April 2012 it was shown that the frequency of rain occurred in the morning (08.0012.00 hours) as much as $13 \mathrm{~mm} /$ hour, then the frequency of rain occurred during the day (12.0018.00 hours) by $103 \mathrm{~mm} /$ hour, while the frequency of huh does not occur at night (20.00-24.00 hours).

In April 2013 showed that the frequency of rain occurred in the morning (08.00-12.00 hours) as much as $63 \mathrm{~mm} /$ hour, then the frequency of rain occurred during the day (12.00-18.00 hours) as much as $137 \mathrm{~mm} /$ hours, and the frequency of rain occurs at night (18.00-24.00 hours) as much as $38 \mathrm{~mm} / \mathrm{hour}$.

In April 2014 showed that the frequency of rain occurred in the morning (08.00-12.00 hours) as much as $1 \mathrm{~mm} /$ hour, then the frequency of rain occurred during the day (12.00-18.00 hours) as much as $38 \mathrm{~mm} /$ hour, and the frequency of rain occurs at night at 18:00 to 24:00 a day of $207 \mathrm{~mm} /$ hour. 


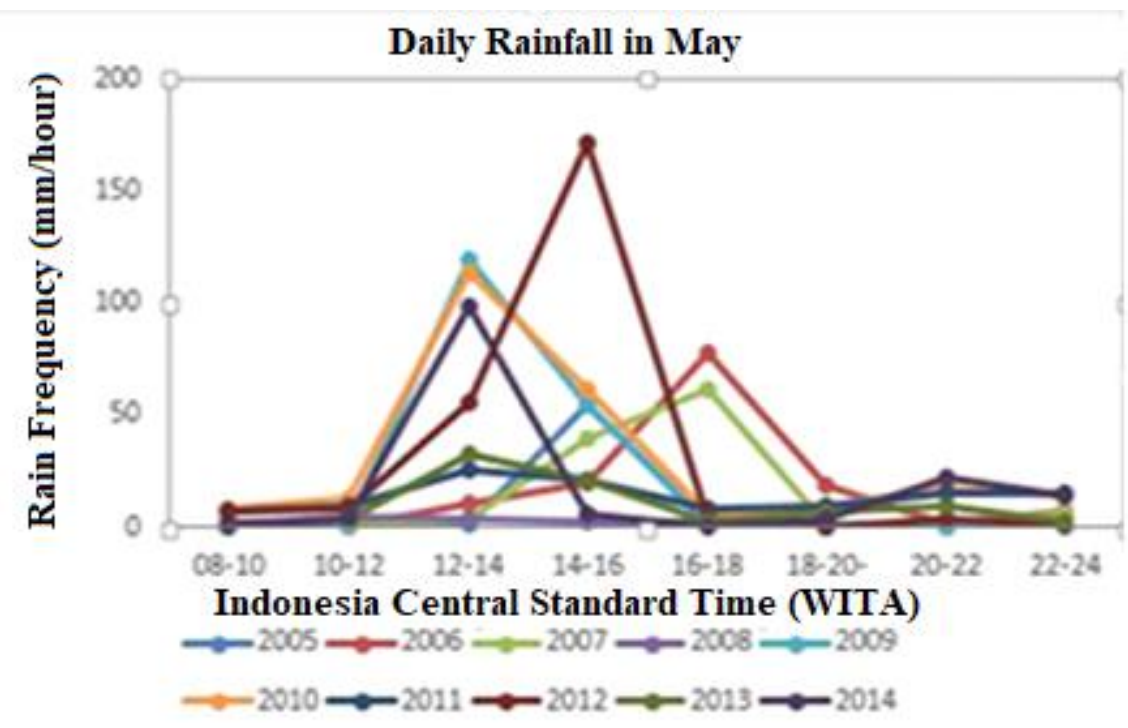

Figure graph 3. Bulk frequency for a daily duration of 3 hours in May in Makassar .

Based figure 3, it is a graph of the frequency of daily rainfall of 3 hours duration in Makassar which has been processed in 2005-2014 for 10 years in May as follows.

In May 2005 showed that the frequency of rain occurred in the morning (08.00-12.00 hours) as much as $1 \mathrm{~mm} /$ hour, then the frequency of rain occurred during the day (12.00-18.00 hours) at $55 \mathrm{~mm} /$ hour, and the frequency of rain occurs at night (18.00-24.00 hours) at a rate of $2 \mathrm{~mm} /$ hour.

In May 2006 showed that the frequency of rain occurred in the morning (8:00 a.m. to 12:00 a.m.) by $2 \mathrm{~mm} / \mathrm{hour}$, then the frequency of rain occurred during the day (12:00-18: 00 hours) by $78 \mathrm{~mm} /$ hour, and the frequency of rain occurs at night (20.00-24.00 hours) at a rate of $19 \mathrm{~mm} /$ hour.

In May 2007 showed that the frequency of rain occurred in the morning (08.00-12.00 hours) as much as $1 \mathrm{~mm} /$ hour, then the frequency of rain occurred during the day (12.00-18.00 hours) at $61 \mathrm{~mm} /$ hour, and the frequency of rain occurs at night (18.00-24.00 hours) as much as $6 \mathrm{~mm} /$ hour.

In May 2008 showed that the frequency of rain occurred in the morning (08.00-12.00 hours) as much as $5 \mathrm{~mm} /$ hour, then the frequency of rain occurred during the day (12.00-18.00 hours) at $3 \mathrm{~mm} /$ hour, and the frequency of rain occurs at night (18.00-24.00 hours) at a rate of 1 $\mathrm{mm} / \mathrm{hour}$.

In May 2009 showed that the frequency of rain occurred in the morning (08.00-12.00 hours) at $1 \mathrm{~mm}$ /hour. then the frequency of rain occurs during the day (12.00-18.00 hours) as much as $119 \mathrm{~mm} /$ hour, and the frequency of rain occurs at night (18.00-24.00 hours) as much as $1 \mathrm{~mm} /$ hour.

In May 2010 showed that the frequency of rain occurred in the morning (08.00-12.00 hours) as much as $13 \mathrm{~mm} /$ hour, then the frequency of rain occurred during the day (12.00-18.00 
$184 \mid$ Jurnal Administrare: Jurnal Pemikiran Ilmiah dan Pendidikan Administrasi Perkantoran
Volume 6 Number 2 July- December 2019. Pages 177-188

hours) a lot of $113 \mathrm{~mm} /$ hour, and the frequency the rain happened at night (18.00-24.00 hours) as much as $17 \mathrm{~mm} /$ hour.

In May 2011 showed that the frequency of rain occurred in the morning (08.00-12.00 hours) as much as $9 \mathrm{~mm} /$ hour, then the frequency of rain occurred during the day (12.00-18.00 hours) at $25 \mathrm{~mm} /$ hour, and the frequency of rain occurs at night (18:00 to 24:00 hours) as much as $15 \mathrm{~mm} /$ hour.

In May 2012 showed that the frequency of rain occurred in the morning (08.00-12.00 hours) as much as $8 \mathrm{~mm} / \mathrm{hour}$. then the frequency of rain occurs during the day (12.00-18.00 hours) at a rate of $172 \mathrm{~mm} /$ hour. The frequency of rain occurs at night (18.00-24.00-wita) as much as $3 \mathrm{~mm} /$ hour.

In May 2013 showed that the frequency of rain occurred in the morning (08.00-12.00 hours) as much as $4 \mathrm{~mm} /$ hour, then the frequency of rain occurred during the day (12.00-18.00 hours) at $32 \mathrm{~mm} /$ hour, and the frequency of rain occurs at night (18:00 to 24:00 hours) as much as $9 \mathrm{~mm} /$ hour.

In May 2014 showed that the frequency of rain occurred in the morning (08.00-12.00 hours) as much as $4 \mathrm{~mm} /$ hour, then the frequency of rain occurred during the day (12.00-18.00 hours) at $99 \mathrm{~mm} /$ hour. and the frequency of rain occurs at night (18.00-24.00 hours) at a rate of $22 \mathrm{~mm} /$ hour.

Transition Season II (Occurs in October and November)

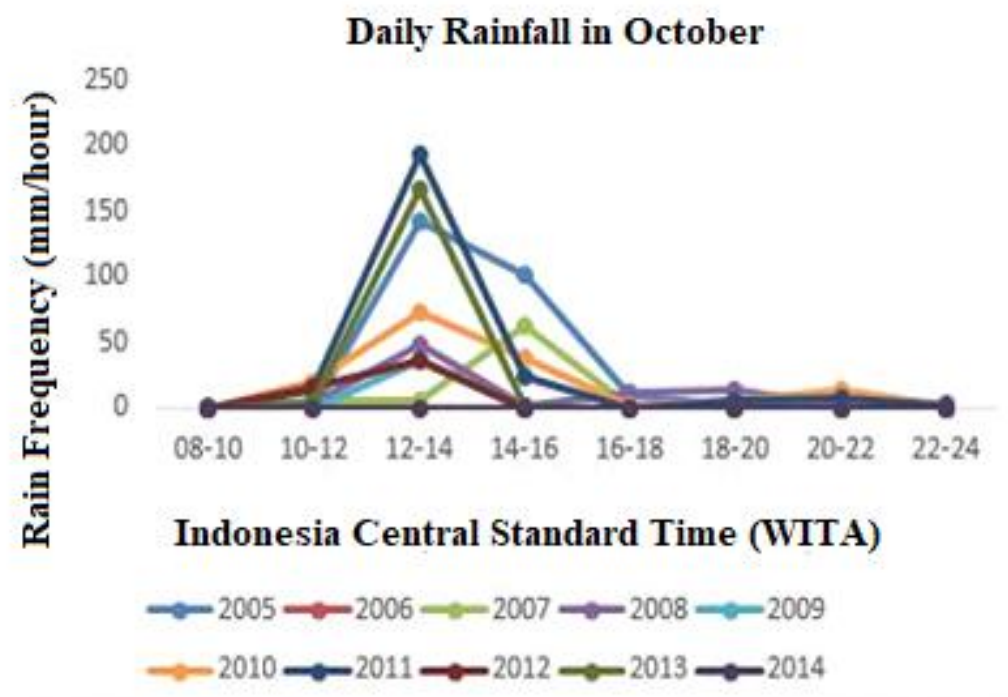

Figure 4. The frequency of rainfall is only the duration of 3 hours in October in Makassar.

Based on figure 4, which is a graph of the frequency of daily duration of 3 hours duration in Makassar which has been processed in 2005-2014 for 10 years in October as follows.

In October 2005 showed that the frequency of rain did not occur in the morning (08.0012.00 hours) because there was no rain, then the frequency of rain occurred during the day 
(12.00-18.00 hours) as much as $143 \mathrm{~mm} /$ hour, and the frequency of rain occurs at night (18.0024.00 hours) as much as $6 \mathrm{~mm} /$ hour.

In October 2006 showed that the frequency of rain in the morning (08.00-12.00 hours), then the frequency of rain during the day (12.00-18.00 hours), and the frequency of rain at night (18.00-24.00) no because there was no rain that month.

In October 2007 showed that the frequency of rain occurred in the morning (8:00 a.m. to 12:00 a.m.) a total of $5 \mathrm{~mm} / \mathrm{hour}$, then the frequency of rain occurred during the day (12:00 to 18:00 hours) as much as $62 \mathrm{~mm} / \mathrm{hours}$, and the frequency of the night at night (18.00-24.00 hours) is not there because there is no rain.

In October 2008 it was shown that the frequency of rain occurred in the morning (8:00 a.m. to 12:00 a.m.) a total of $4 \mathrm{~mm} /$ hour, then the frequency of rain occurred during the day (12:00 to 18:00 hours) as much as $49 \mathrm{~mm} /$ hour, and the frequency of January occurs at night (18:00 to $24: 00$ hours) by $13 \mathrm{~mm} /$ hour.

In October 2009 it was shown that the frequency of rain occurred during the day (12.0018.00 hours) a total of $35 \mathrm{~m} /$ hour, whereas in the morning (8.00-12.00) and at night (18.0024.00 hours) no because there is no rain.

In October 2010 it was shown that the frequency of rain occurred in the hours $(08.00$ 12.00 hours) as much as $19 \mathrm{~mm} / \mathrm{hour}$, then the frequency of rain occurred during the day (12.0018.00 hours) as much as $73 \mathrm{~mm} /$ hour, and the frequency rain occurs at night (18.00-24.00 hours) as much as $14 \mathrm{~mm} /$ hour.

In October 2011 showed that the frequency of rain occurred in the morning (08.00-12.00 hours) as much as $14 \mathrm{~mm} /$ hour, then the frequency of rain occurred during the day (12.0018.00-wita) as many as $194 \mathrm{~mm} /$ hour, and the frequency of rain occurs at night occurs at (18:00 - 24:00 hours) as much as $7 \mathrm{~mm} /$ hour.

In October 2012 it was shown that the frequency of rain occurred in the morning (08.0012.00 hours) by $16 \mathrm{~mm} / \mathrm{hour}$, then the frequency of rain occurred at noon (12.00-18.00 hours) as much as $36 \mathrm{~mm} /$ hour, and the frequency of rain at night (18.00-24.00 hours) is not there because there is no rain.

In October 2013 it was shown that the frequency of rain occurred in the morning (08.0012.00 hours) by $3 \mathrm{~mm} / \mathrm{hour}$, then the frequency of rain occurred during the day (12.00-18.00 hours) as much as $168 \mathrm{~mm} /$ hour , and the frequency of rain at night (18.00-24.00 hours) is not there because there is no rain.

In October 2014 showed that the frequency of rain in the morning (08.00-14.00 hours), during the day (at 14.00-20.00 hours), and at night (at 20.00-24.00 hours) is not there because there is no rain. 


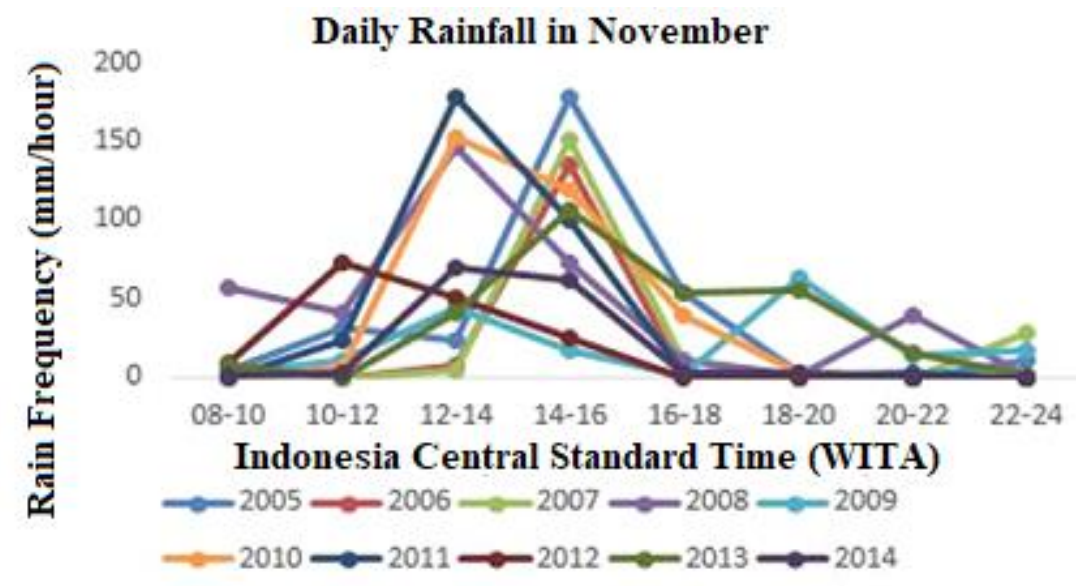

Figure 5. Rainfall frequency is only 3 hours in November in Makassar

Based on figure 5, which is a graph of the frequency of daily duration of 3 hours duration in Makassar which has been processed in 2005-2014 for 10 years in November as follows:

In November 2005 showed that the frequency of rain occurred in the morning (08.0012.00 hours), $32 \mathrm{~mm} /$ hour, then the frequency of rain occurred during the day (12.00-18.00 hours) as much as $178 \mathrm{~mm} /$ hour, and frequency rain occurs at night (18.00-24.00 hours) as much as $10 \mathrm{~mm} /$ hour.

In November 2006 showed that the frequency of rain occurred during the day (12.0018.00 hours) as much as $135 \mathrm{~mm} /$ hour, while the frequency of rain in the morning (8.00-12.00), and at night (18.00-24.00) there was no because there is no rain.

In November 2007 showed that the frequency of rain occurs in the morning (08.00-12.00 hours) as much as $3 \mathrm{~mm} /$ hour, then the frequency of rain occurs during the day (12.00-18.00 hours) as much as $151 \mathrm{~mm} /$ hour, and the frequency of rain occurs at night (18.00-24.00 hours) as much as $28 \mathrm{~mm} / \mathrm{hour}$.

In November 2008 showed that the frequency of rain occurred in the morning (08.0012.00 hours) at $57 \mathrm{~mm} /$ hour, then the frequency of rain occurred during the day (12.00-18.00 hours) as much as $146 \mathrm{~mm} /$ hour, and the frequency rain occurs at night (18.00-24.00 hours) as much as $40 \mathrm{~mm} /$ hour.

In November 2009 showed that the frequency of rain occurred in the morning (08.0012.00 hours) at $10 \mathrm{~mm} /$ hour, then the frequency of rain occurred during the day (12.00-18.00 hours) as much as $44 \mathrm{~mm} /$ hour, and the frequency rain occurs at night (18.00-24.00 hours) as much as $63 \mathrm{~mm} /$ hour.

In November 2010 it was shown that the frequency of rain occurred in the morning (08.00-12.00 hours) at $6 \mathrm{~mm} /$ hour, then the frequency of rain occurred during the day (12.0018.00 hours) as much as $153 \mathrm{~mm} /$ hour, and frequency rain occurs at night (18.00-24.00 hours) as much as $2 \mathrm{~mm} /$ hour.

In November 2012 showed that the frequency of rain occurred in the morning (08.0012.00 hours) as much as $73 \mathrm{~mm} /$ hour, then the frequency of rain occurred during the day (12.0018.00 hours) as much as $50 \mathrm{~mm} /$ hour, and frequency Rain at night (18.00-24.00 WIB) does not exist because there is no rain. 
In November 2013 showed that the frequency of rain occurred in the morning (08.0012.00 hours) at $8 \mathrm{~mm} /$ hour, then the frequency of rain occurred during the day (12.00-18.00 hours) as much as $107 \mathrm{~mm} /$ hour, and frequency rain occurs at night (18.00-24.00 hours) as much as $55 \mathrm{~mm} /$ hour.

In November 2014 showed that the frequency of rain occurs in the morning (08.00-12.00 hours) as much as $2 \mathrm{~mm} /$ hour, then the frequency of rain occurs during the day (12.00-18.00wita) as much as $70 \mathrm{~mm} /$ hour, and the frequency of rain occurs at night (18.00-24.00 hours) as much as $2 \mathrm{~mm} /$ hour.

Based on the results of the processing of rainfall data carried out for 30 years (period 1985-2014), it can be seen that Makassar City has a monsoonal pattern. In the graph of the monsoonal monthly rainfall pattern, it can be seen that during the rainy season the peak rainfall intensity is once a year (unimoda) which occurs in December, January and February. In December, January and February, the average monthly rainfall accumulates more than $150 \mathrm{~mm}$. Whereas in the dry season the monthly rainfall intensity is at least once a year which occurs in June, July and August. In June, July, August has an average monthly rainfall accumulation of less than $150 \mathrm{~mm}$.

During the first transition season, the rainy season changes to the dry season or also called the dry season/dry season. The dry or dry season is in the tropics which is influenced by the monsoon system. Called the dry season, because monthly rainfall must be below $60 \mathrm{~mm}$ per month (20 mm/consecutive) for three consecutive decades.

In the second transition season (the change of the dry season to the rainy season) or the so-called wet season or wet season is the season with characteristics of increasing rainfall in a region compared to usually within a certain period of time permanently. Technically, meteorology, the rainy season is thought to begin to occur if the rainfall in the three consecutive has exceeded $100 \mathrm{~mm} / \mathrm{m}^{2}$ per consecutive and continues.

In general, the frequency of rain in the transition period I is in April where the dominant rainfall occurs during the day (12.00-14.00 hours) while in May where the dominant rainfall occurs during the day (12.00 - 16.00 hours). The frequency of rain in the transition season II in October where the dominant rainfall occurs during the day (12.00-16.00 hours). Whereas in November rainfall is spread evenly in each time span or interval (morning to night) with the highest frequency occurring during the day (12.00-16.00 hours).

\section{CONCLUSION}

Based on the results and discussion, it can be concluded as follows: The monthly rainfall pattern that occurs in Makassar City is a monsoonal rain pattern with two peaks of rain that occur in January and December and the smallest intensity of rainfall in August. In the transition season, the frequency of rain that occurs in the city of Makassar is: the frequency of rain in the morning (08.00-12.00 hours) predominantly in November with the highest rainfall of $73 \mathrm{~mm}$ /hours, the frequency of rain during the day (12.00-18.00 hours) is dominant in May with the highest rainfall of $194 \mathrm{~mm} /$ hour and the frequency of rain at night (18.00-24.00 local time) is dominant in April with the highest rainfall of $207 \mathrm{~mm} / \mathrm{hour}$. 
188 Jurnal Administrare: Jurnal Pemikiran Ilmiah dan Pendidikan Administrasi Perkantoran

Volume 6 Number 2 July- December 2019. Pages 177-188

\section{REFERENCES}

Carvalho, L. (2002). Extreme Preciitation Events in Southeastern South America and Large Scale Convective Patterns in the South Atlantic Convergence Zone. Journal of Climate, 23(77), 23-94.

Davolio, S. B. (2012). Analyzes of Heavy Precipitation Events Over Ligurian Region. . Institute of Atmospheric Science and Climate (ISAC) of the Italian National Research Coil (CNR).

Galvan, L. (2013). Rainfall estimation in SWAT: an alternative method to simulate orographic precipitation. Journal of Hydrology, 509, 257-265.

Giannini, A., Robertson, A. W., \& Qian, J. H. (2007). A role for tropical tropospheric temperature adjustment to El Niño-Southern Oscillation in the seasonality of monsoonal Indonesia precipitation predictability. Journal of Geophysical Research Atmospheres. https://doi.org/10.1029/2007JD008519

Handoko. (1994). Basic Climatology: The Foundation for Understanding Atmospheric Physics and Climate Elements. Bogor: IPB Publishing Agency.

Hendon, H. . (2003). Indonesian rainfall variability: impacts of ENSO and local air-sea interaction. Journal of Climate, 16, 1775-1790.

Hilario, F. (2009). El Niño Southern Oscillation in the Philippines: impacts, forecasts, and risk management. Philippine Journal of Development, 36(66).

Jones, C. O. (2004). An introduction to the study of public policy. Massachusetts: Duxbury Press.

Nontji, A. (2002). Laut Nusantara (Third Prin). Jakarta: Djambat Issuing Agency.

Qian, J. H. (2008). Why precipitation is mostly concentrated over Islands in the Maritime Continent. Journal of The-Atmospheric Sciences, 65, 1428-1441.

Ropelewski, C. F., \& Halpert, M. S. (1987). Global and Regional Scale Precipitation Patterns Associated with the El Niño/Southern Oscillation. Monthly Weather Review. https://doi.org/10.1175/1520-0493(1987)115<1606:garspp>2.0.co;2

Soewarno. (1995). Hydrology Application of Volume I. Bandung: Nova Publishing Agency. 